\title{
Cardiovascular effects induced by the hydroalcoholic extract of the stem of Xylopia cayennensis in rats
}

\author{
Alessandra A. Nascimento, Eurica A. Nogueira Ribeiro, Joelisia M. Oliveira, Fernando A. \\ Medeiros, Marcelo S. Silva, Isac A. Medeiros* \\ Laboratório de Tecnologia Farmacêutica "Delby Fernandes de Medeiros”, Universidade Federal da Paraíba, \\ Caixa Postal 5009, 58051-970, João Pessoa, PB, Brazil
}

\begin{abstract}
RESUMO: "Efeitos cardiovasculares induzidos pelo extrato hidroalcoólico das cascas de Xylopia cayennensis em ratos". Os efeitos cardiovasculares induzidos pelo extrato hidroalcoólico do caule de Xylopia cayennensis (EHXC) foram estudados em ratos, utilizando uma abordagem combinada in vivo e in vitro. Em ratos não anestesiados, EHXC induziu uma hipotensão não dependente de dose associada com um aumento da freqüência cardíaca. Esta resposta hipontesora não foi atenuada depois do bloqueio com L-NAME (20 mg/Kg, i.v.). Em anéis de aorta isolados de rato, EHXC foi capaz de relaxar o tônus induzido por fenilefrina $(1 \mu \mathrm{M})$ e $\mathrm{KCl}(80 \mathrm{mM}),\left(\mathrm{CE}_{50}\right.$ $=85 \pm 13$ e $62 \pm 5 \mu \mathrm{g} / \mathrm{mL}$, respectivamente). A atividade vasorelaxante do HEXC não foi inibida pela remoção do endotélio vascular $\left(\mathrm{CE}_{50}=58 \pm 6 \mu \mathrm{g} / \mathrm{mL}\right)$. HEXC antagonizou as contrações induzidas por $\mathrm{CaCl}_{2}$ em meio despolarizante nominalmente sem $\mathrm{Ca}^{+2}$. $\mathrm{EHXC}$ antagonizou de maneira dependente de concentração as contrações transientes induzidas por cafeína $(20 \mathrm{mM})$, em meio livre de $\mathrm{Ca}^{2+}$, contudo não alterou aquelas induzidas por noradrenalina $(1 \mu \mathrm{M})$. Em átrio isolado de rato, EHXC induziu um efeito inotrópico e cronotrópico negativo $\left(\mathrm{CI}_{50}=534 \pm 42 \mu \mathrm{g} / \mathrm{mL}\right.$ e $259 \pm 22 \mu \mathrm{g} / \mathrm{mL}$; respectivamente). Os resultados obtidos demonstram que EHXC apresenta um potente efeito hipotensor, provavelmente conseqüência da diminuição da resistência periférica total que parece ser, em parte, devido a uma ação inibitória sobre o influxo de $\mathrm{Ca}^{+2}$ através de canais de cálcio dependentes de voltagem e também através da inibição da liberação de $\mathrm{Ca}^{+2}$ dos estoques intracelulares sensíveis à cafeína. HEXC atua diretamente no coração diminuindo a contratilidade e a freqüência cardíaca, estes efeitos têm importância pequena na expressão da resposta hipotensiva induzida por HEXC.
\end{abstract}

Unitermos: Xylopia cayennensis, Annonaceae, efeitos cardiovasculares, átrio isolado de rato, anéis aórticos isolado de rato, influxo de $\mathrm{Ca}^{2+}$.

\begin{abstract}
The cardiovascular effects induced by the hydroalcoholic extract of the stem of Xylopia cayennensis (HEXC) were studied in rats using a combined in vivo and in vitro approach. In non-anesthetized rats, HEXC injections produced a significant and dose-dependent hypotension associated with an increase in heart rate. The hypotensive response was not attenuated after nitric oxide (NO) synthase blockade, L-NAME $(20 \mathrm{mg} / \mathrm{Kg}$, i.v.). In isolated rat superior aortic rings, $\mathrm{HEXC}$ was able to relax the tonus induced by phenylephrine $(1 \mu \mathrm{M})$ and $\mathrm{KCl}(80 \mathrm{mM}),\left(\mathrm{EC}_{50}\right.$ $=85 \pm 13$ and $62 \pm 5 \mu \mathrm{g} / \mathrm{mL}$, respectively). The smooth muscle-relaxant activity of HEXC was not inhibited by removal of vascular endothelium $\left(\mathrm{EC}_{50}=58 \pm 6 \mu \mathrm{g} / \mathrm{mL}\right)$. HEXC antagonized $\mathrm{CaCl}_{2}$-induced contractions in depolarizing medium nominally without $\mathrm{Ca}^{2+}$. $\mathrm{HEXC}$ inhibited the intracellular calcium-dependent transient contractions induced by caffeine $(20 \mathrm{mM})$ in $\mathrm{Ca}^{2+}$ free solution, but not those induced by norepinephrine $(1 \mu \mathrm{M})$. In isolated rat atrial preparations, $\mathrm{HEXC}$ produced negative inotropic and chronotropic responses $\left(\mathrm{IC}_{50}=534 \pm 42\right.$ and $259 \pm 22 \mu \mathrm{g} / \mathrm{mL}$, respectively). The results obtained suggest that the hypotensive effect of HEXC is probably due to a peripheral vasodilatation, at least, secondary to an interference with the $\mathrm{Ca}^{2+}$ mobilization as a consequence of voltage-dependent $\mathrm{Ca}^{2+}$ channel blockade and the inhibition of $\mathrm{Ca}^{2+}$ release from caffeine-sensitive intracellular stores. Finally, HEXC acts directly on the heart decreasing contractility and heart rate, these effects are of little importance to the expression of the hypotensive response induced by HEXC.
\end{abstract}

Keywords: Xylopia cayennensis, Annonaceae, cardiovascular effects, isolated atria, isolated rat aortic rings, $\mathrm{Ca}^{2+}$ influx.

\section{INTRODUCTION}

In the genus Xylopia comprises more than
2300 species which are widely distributed in 130 genus, throughout exclusively of tropical areas as Amazônica area. Xylopia cayennensis is a plant of the family Anonaceae, 


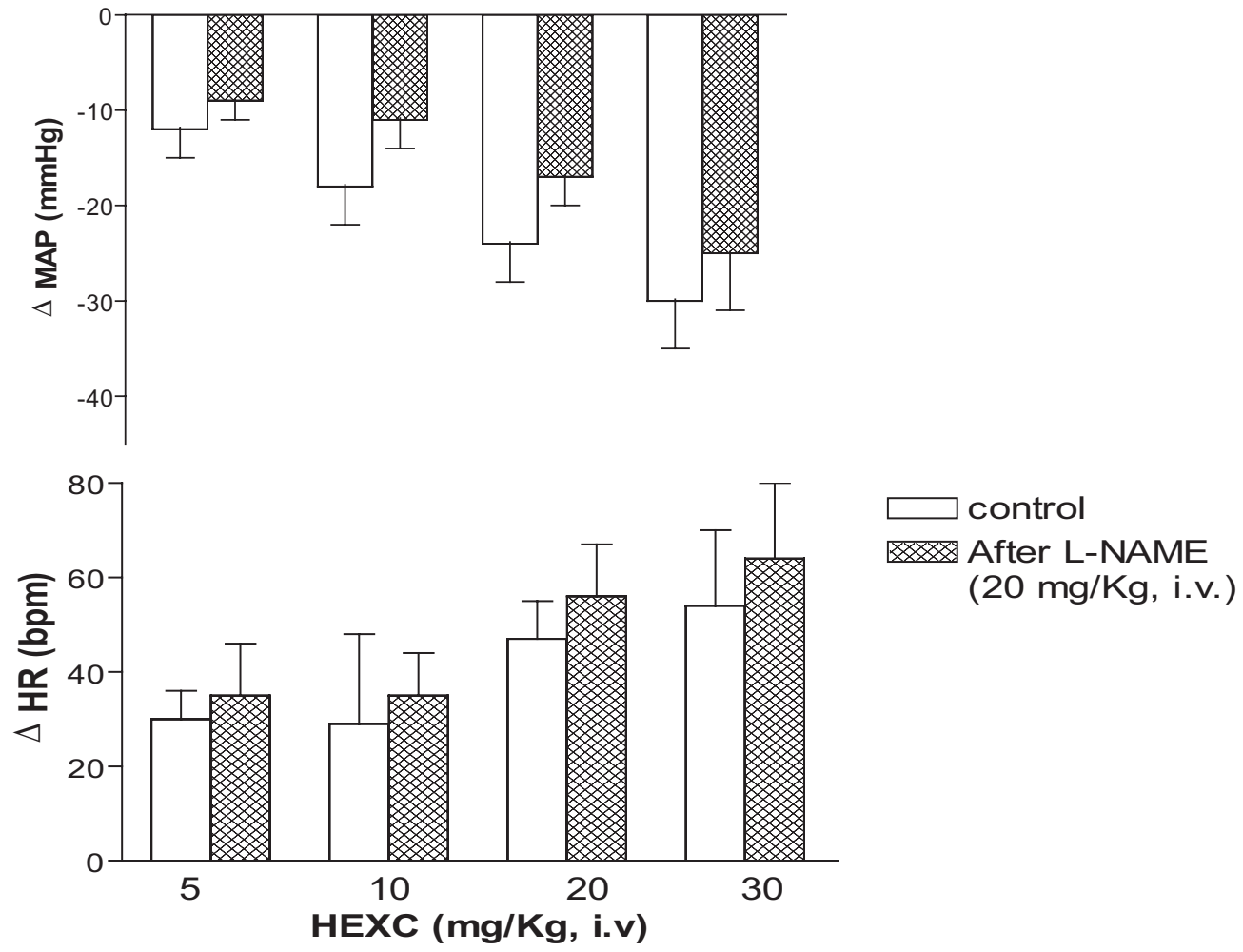

Figure 1. Bar graphs show peak changes in mean arterial pressure (MAP), and heart rate (HR) induced by the acute administration of increasing doses of $\operatorname{HEXC}(5,10,20$ and $30 \mathrm{mg} / \mathrm{Kg}$, i.v.) in conscious unrestrained normotensive rats, before (control) and after NO-synthase inhibition (After L-NAME). Values are means \pm s.e.m. $(n=6)$.

popularly known as "embira". Other species of the genus Xylopia presents several pharmacological activities but we didn't find in the literature any specific study involving the pharmacological activity of this specie. A computer aided search (NAPRALERT, College of Pharmacy, University of Illinois at Chicago-USA) failed to show any study concerning the pharmacology of the Xylopia cayennensis. However, it is well reported in the literature that other species of the genus Xylopia possess activity as antimicrobial (X. aethiopica, $X$. sericea) (Malcolm; Sofowora, 1969; Matos, 1986; Lemos et al., 1992), antifungal (X. Aethiopica, X. frutensis) (Awuah, 1989; Rahalison et al., 1993), antimalarial and anticonvulsant activities in mice (X. aethiopica) (Etkin, 1997; Adesina, 1982). In the present work, we attempted to characterize the cardiovascular effects induced by HEXC, by using a combined in vivo and in vitro approach.

\section{MATERIAL AND METHODS}

Male Wistar rats (200-300 g) were used for all experiments. Experimental protocols and procedures were approved by the Laboratório de Tecnologia Farmacêutica Animal Care and Use Committee. The plant was collected in state of Amapá and a voucher specimen was deposited in the Herbarium of the Institute of Research Scientific and Technological, state of Amapá, Code 041585. The stems were separated, dried at $40{ }^{\circ} \mathrm{C}$ in an oven and pulverized. The powder was extracted with $96 \%$ ethanol in water at room temperature $\left(25-30^{\circ} \mathrm{C}\right)$ for $72 \mathrm{~h}$. The resulting extract was dried at $40^{\circ} \mathrm{C}$ using a rotavaporator and the yield was c.a. $22 \%$. When required, this extract was dissolved in distilled water, filtered and known volumes were dried to determine the concentration.

For measurement of arterial blood pressure and heart rate, we used the technique described by (Cerutti et al., 1985). The thoracic aortic was removed and cleaned from connective tissue and fat. Rings of 3-4 $\mathrm{mm}$ were suspended horizontally between two stainless steel wires and mounted in a $10 \mathrm{~mL}$ organ chamber filled with warmed $\left(37{ }^{\circ} \mathrm{C}\right)$ and oxygenated $\left(95 \% \mathrm{O}_{2}\right.$ and $5 \%$ $\mathrm{CO}_{2}$ ) Krebs' solution. Mechanical activity was recorded isometrically by a force transducer (FORT-10, WPI, Sarasota, FL, USA). The tissues were allowed to stabilize for 1 hour in Kreb's solution with a resting tension of $1 \mathrm{~g}$. HEXC were cumulatively applied. Inhibition was calculated comparing the response of the contractile agents before and after the addition of the HEXC. $\mathrm{EC}_{50}$ and $\mathrm{IC}_{50}$ values were calculated by linear regression of individual concentration response curves. The presence of functional endothelium was assessed by the ability of acetylcholine (ACh, $1 \mu \mathrm{M})$ to induce more than $70 \%$ relaxation of vessels pre-contracted with phenylephrine $(1 \mu \mathrm{M})$. Rat atria were isolated according to the technique 


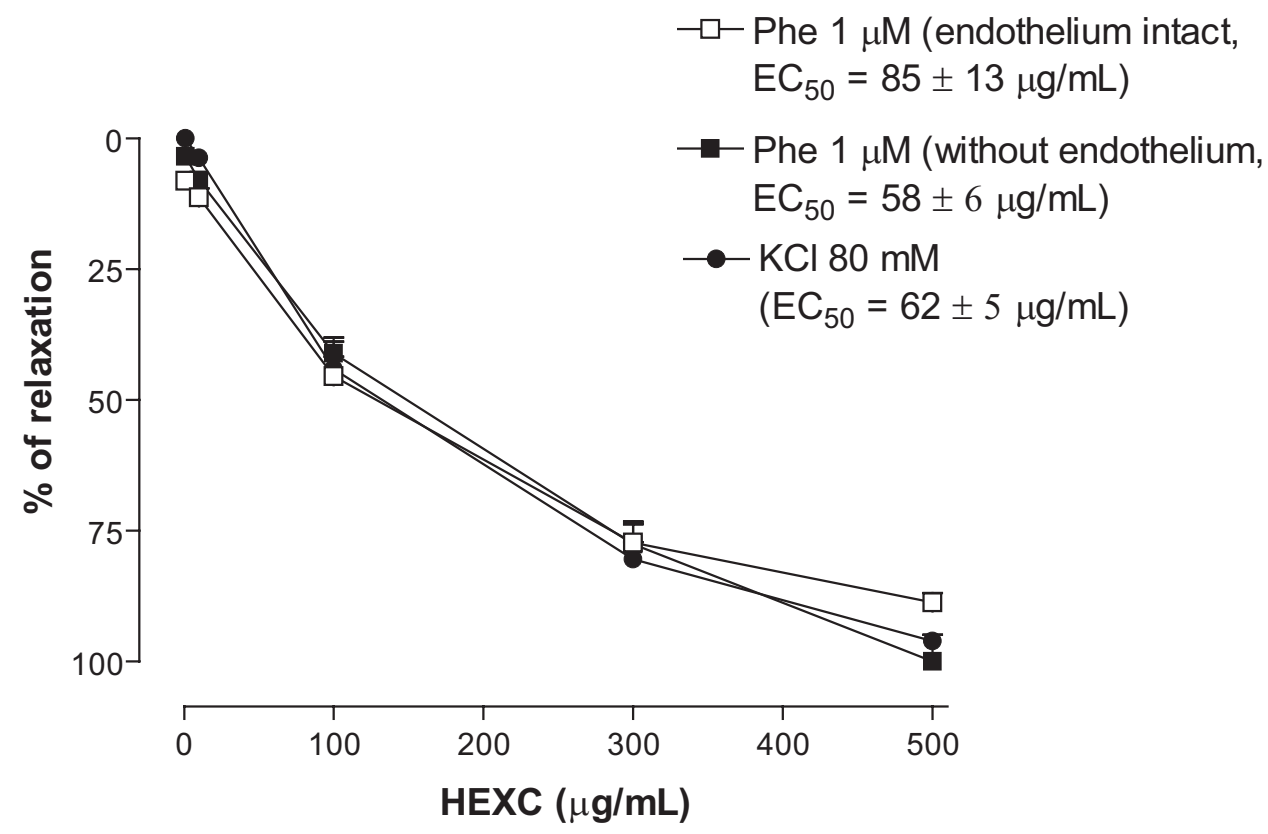

Figure 2. Line plot graph showing the effects of increasing concentrations of $\operatorname{HEXC}(1,10,100,300$ and 500 $\mu \mathrm{g} / \mathrm{mL})$ in phenylephrine $(1 \mu \mathrm{M})$ and $\mathrm{KCl}(80 \mathrm{mM})$ induced contractions in aortic rings. Values are mean \pm s.e.m $(n=6)$.

described by Nasa et al., 1992. Cumulative concentrationresponse curves were constructed by stepwise addition of HEXC. In some experiments, the rate of spontaneous beating of the atria was measured, being defined as atrial rate, to assess the chonotropic effects of HEXC. Values are expressed as mean \pm s.e.mean. Statistical analysis was performed by means of paired Student's $t$-test when appropriate. Linear regressions were done by the least square method.

\section{RESULTS AND DISCUSSION}

In conscious rats, baseline values of mean arterial pressure (MAP) and heart rate (HR) were $111 \pm 1$ $\mathrm{mmHg}$ and $366 \pm 7 \mathrm{bpm}$ respectively. $\operatorname{HEXC}(5,10,20$ and $30 \mathrm{mg} / \mathrm{kg}$ i.v., randomly) produced a dose-dependent hypotension associated with an increase in the heart rate. As endothelium-derived NO plays an important role in the regulation of blood pressure and vascular tone (Rees et al., 1989; Moncada et al., 1991) it is possible to assume

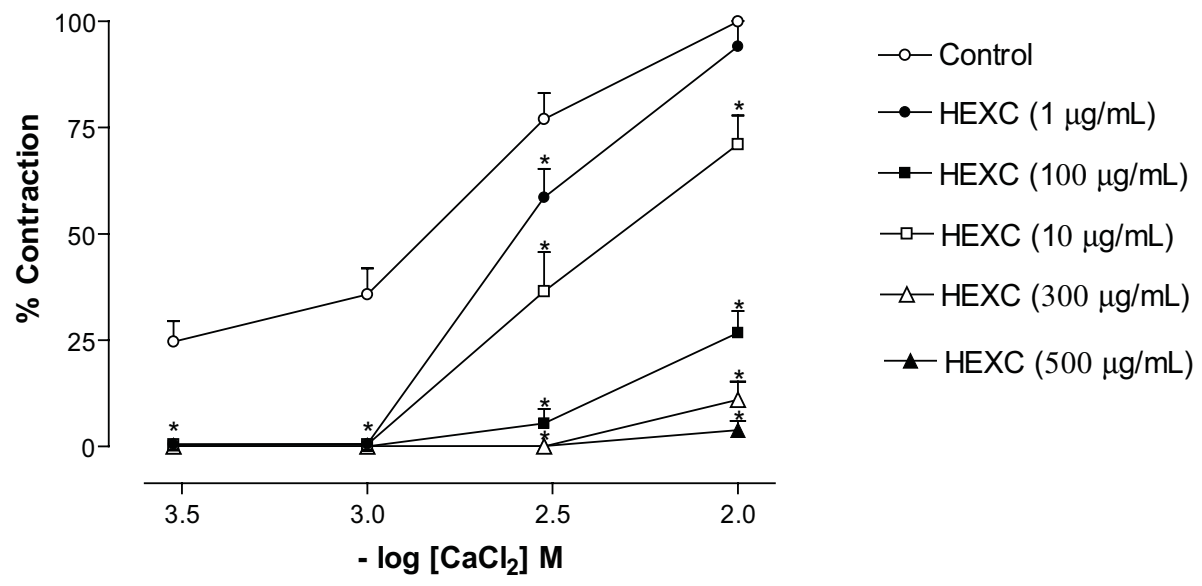

Figure 3. Line plot graph showing the effects of concentration HEXC on cumulative concentrationresponse curves to $\mathrm{CaCl}_{2}$ in nominally without $\mathrm{Ca}^{2+}$ depolarizing medium in rat isolated aortic rings (n $=6$ ). Values are mean \pm s.e.m. $* \mathrm{p}<0.05$ vs control. 


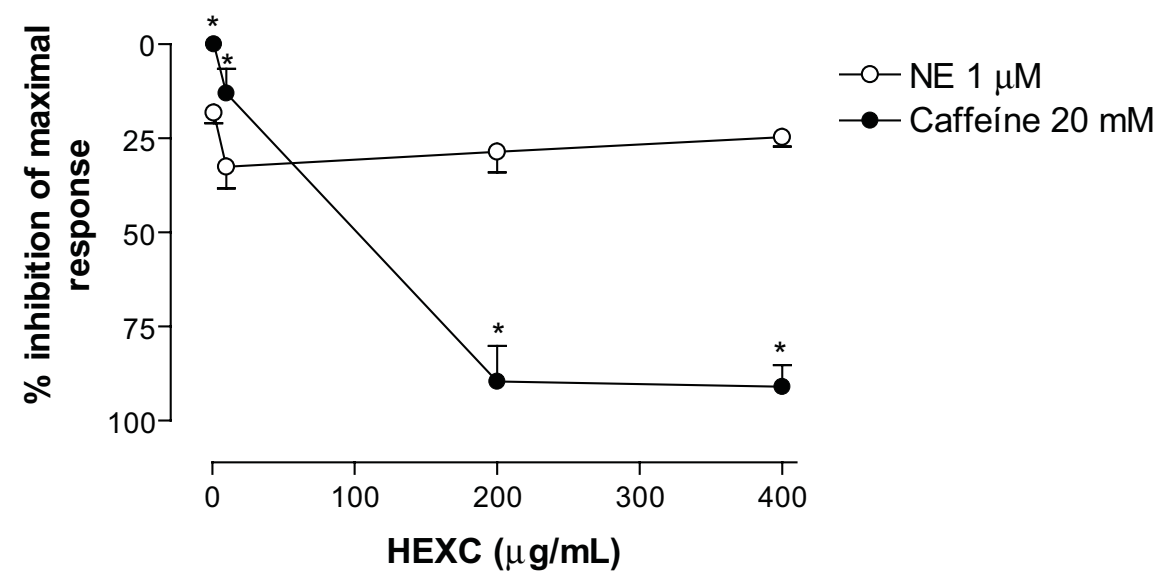

Figure 4. Line plot graph showing the effects of increasing concentrations of $\operatorname{HEXC}(1,10$, $100,200$ and $400 \mu \mathrm{g} / \mathrm{mL})$ on norepinephrine $(1 \mu \mathrm{M})$ and caffeine $(20 \mathrm{mM})$-induced transient contractions in $\mathrm{Ca}^{2+}$-free media, in rat isolated superior aortic rings, $(\mathrm{n}=6)$. Values are mean \pm s.e.m.

that the decrease in blood pressure may be due to NO release from vascular endothelium. In the presence of NO-synthase inhibition (L-NAME $20 \mathrm{mg} / \mathrm{Kg}$, i.v.), hypotension induced by HEXC was similar to that induced by the extract given alone, suggesting that the hypotensive action of HEXC in conscious normotensive rats is independent of NO release from vascular endothelium (Figure 1). Furthermore, tachycardia may be reflex in origin.

In isolated aortic rings, $\operatorname{HEXC}(1,10,100,300$ and $500 \mu \mathrm{g} / \mathrm{mL}$ ) antagonized in a concentration-dependent manner the contractions induced by phenylephrine, in rings in which endothelium was intact and in which the endothelium was mechanically removed $\left(\mathrm{EC}_{50}=85 \pm 13\right.$ and $58 \pm 6 \mu \mathrm{g} / \mathrm{mL}$, respectively) the magnitude of inhibition was similar in both preparations. Taken together, these results indicate that relaxing factors released by the endothelium, mostly NO, do not play an important role in the vasorelaxant response to HEXC (Figure 2).

HEXC was able to antagonize, in a concentrationdependent manner, $\mathrm{KCl}(80 \mathrm{mM})$ and phenylephrineinduced contractions with the same magnitude $\left(\mathrm{EC}_{50}=\right.$ $85 \pm 13$ and $62 \pm 5 \mu \mathrm{g} / \mathrm{mL}$, respectively) (Figure 2). The maintenance of smooth muscle contraction depends upon $\mathrm{Ca}^{2+}$ entry from extracellular fluid through voltage and/ or receptor operated calcium channels (VOCC'S and/or ROCC'S, respectively) (Nelson et al., 1990), (Karaki; Weiss, 1988). It is well known that $\mathrm{KCl}$ induces smooth muscle contraction through activation of VOCC'S and subsequent release of calcium from the sarcoplasmic reticulum (Gurney; 1994), without changing other signal transduction systems including phosphatidylinositol

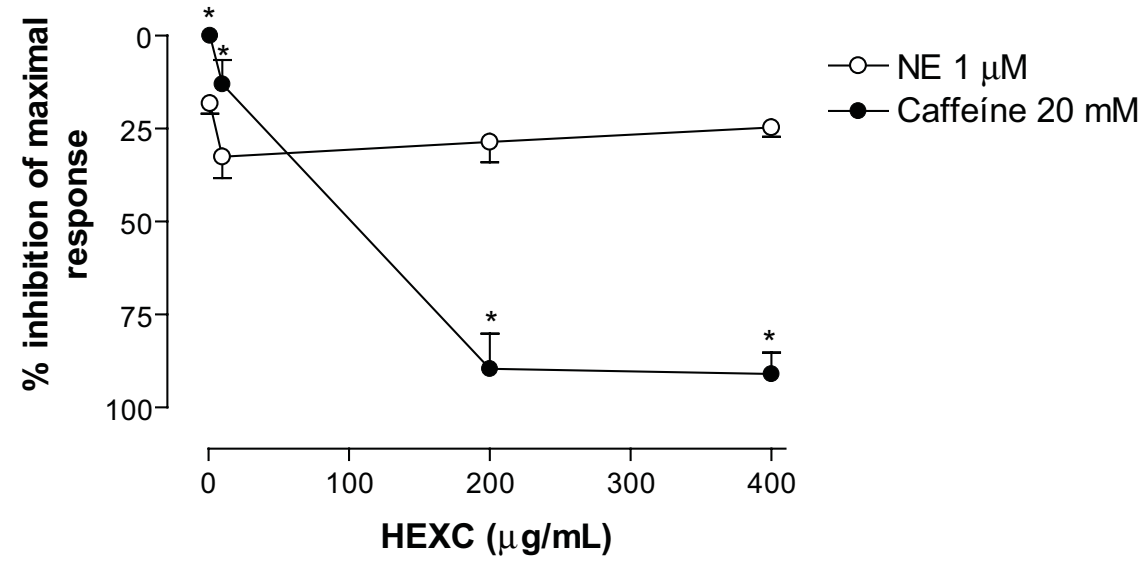

Figure 5. Line plot graph showing the negative inotropic and chonotropic effects of HEXC (2, $20,200,400$ and $600 \mu \mathrm{g} / \mathrm{mL})$ on isolated left and right rat atria. Values are mean \pm s.e.m. $(\mathrm{n}=$ $6)$. 
turnover and calcium sensitization (Karaki et al., 1997). HEXC seems to block VOCC'S as the contractions induced by potassium were inhibited in a concentrationdependent manner. This hypothesis was confirmed by the observation that $\operatorname{HEXC}(1,10,100,300$ and $500 \mu \mathrm{g} / \mathrm{mL})$ inhibited, in a concentration-dependent manner, the $\mathrm{CaCl}_{2}$ induced contractions in depolarizing medium nominally without $\mathrm{Ca}^{2+}$ (Figure 3).

The caffeine induces the $\mathrm{Ca}^{2+}$ release from ryanodine sensitive intracellular stores through the ryanodine receptor activation by $\mathrm{Ca}^{2+}\left(\mathrm{Ca}^{2+}\right.$-induced $\mathrm{Ca}^{2+}$ release mechanism) (Rusko et al., 1995). The activation of phosphoinositide turnover by $\mathrm{G}$ protein coupling of phospholipase $\mathrm{C}$ and alpha-adrenergic, serotonergic (5$\mathrm{HT}_{1 \mathrm{C}}$ ) or prostanoid receptors is crucial for the cytoplasmic calcium increase involved in the contraction induced by activation of these receptors and involves calcium from intracellular stores (Clapham, 1995), (Bootman; Berridge, 1995).

This led us to investigate whether HEXC could exert its non specific spasmolytic actions by interfering with the calcium release induced by phosphoinositide production following receptor activation or $\mathrm{Ca}^{2+}$-induced $\mathrm{Ca}^{2+}$-release mechanism. In this respect, we investigated the effect of HEXC on caffeine and norepinephrineinduced transient contractions in $\mathrm{Ca}^{2+}$-free media. HEXC inhibited transient contractions induced by caffeine but not those induced by norepinephrine (Figure 4). It has been suggested that the caffeine-induced calcium release is due to $\mathrm{Ca}^{2+}$-induced $\mathrm{Ca}^{2+}$-release mechanism and the norepinephrine-induced release of calcium is attributable to receptor-mediated formation of inositol 1, 4, 5-trisphosphate (Clapham, 1995), (Bootman; Berridge, 1995). Thus, HEXC may selectively inhibit the $\mathrm{Ca}^{2+}$ induced $\mathrm{Ca}^{2+}$-release mechanism due to caffeine in rat aortic rings. In isolated rat atrial preparations, HEXC produced negative inotropic and chronotropic responses $\left(\mathrm{IC}_{50}=534 \pm 42\right.$ and $259 \pm 22 \mu \mathrm{g} / \mathrm{mL}$, respectively) (Figure 5). Additional experiments are needed to clear up the mechanisms involved in the direct action of HEXC on the heart.

These results suggest that the hypotensive effect of $\mathrm{HEXC}$ is probably due to a peripheral vasodilation, at least secondary to an inhibition of the $\mathrm{Ca}^{2+}$ mobilization as a consequence of voltage-dependent $\mathrm{Ca}^{2+}$ channel blockade and $\mathrm{Ca}^{2+}$ release from caffeine-sensitive intracellular stores. The non-specific spasmolytic action induced by HEXC can not be attributed to the participation of the vascular endothelium. Finally, HEXC acts directly on the heart decreasing contractility and heart rate, these effects are of little importance to the expression of the hypotensive response induced by HEXC.

\section{REFERENCES}

Adesina SK 1982. Studies on some plants used as anticonvulsants in Amerindian and African traditional medicine.
Fitoterapia 53: 147-162.

Awuah RT 1989. Fungitoxic effects of extracts from some West African plants. Ann Appl Biol 115: 451-453.

Bootman MD, Berridge MJ 1995. The elemental principles of calcium signaling. Cell 83: 675-678.

Cerutti C, Barres C, Paultre CZ, Sassard J 1985. Computer analysis of intraarterially recorded blood pressure in conscious unrestrained rats. J Pharmacol Methods 13: $249-260$.

Clapham DE 1995. Calcium signaling. Cell 80: 259-268.

Etkin NL 1997. Antimalarial plants used by Hausa in Northern Nigeria. Trop Doctor 271: 12-16.

Gurney AM 1994. Mechanisms of drugs-induced vasodilatation. J Pharmacol 46: 242-251.

Karaki H, Ozaki H, Hori M, Mitsui-Saito M, Amano K, Harada K, Miyamoto S, Nakazawa H, Won KJ, Sato K 1997. Calcium movements, distribution, and functions in smooth muscle. Pharmacol Rev 49: 157-230.

Karaki H, Weiss GB 1988. Calcium release in smooth muscle. Life Sci 42: 111-122.

Lemos TLG, Monte FJQ, Matos FJA, Alencar JW, Craveiro AA, Barbosa RCSB, Lima EO 1992. Chemical ompositionand antimicrobial activity of essential oils from Brazilian plants. Fitoterapia 63: 266-268.

Malcolm SA, Sofowora EA 1969. Antimicrobial activity of selected Nigerian folk remedies and their constituent plants. Lloydia 34: 512-517.

Matos MEO 1986. Atividade antimicrobiana de Xylopia sericea. Rev Bras Farmacogn 1(Supl): 29-30.

Moncada S, Palmer RMJ, Higgs EA 1991. Nitric oxide: Physiology, pathophysiology and pharmacology. Pharmacol Rev 43: 109-142.

Nasa Y, Ichihara K, Yoshida R, Abiko Y 1992. Positive inotropic and negative chronotropic effects of (-)cis-diltiazem in rat isolated atria. Brit J Pharmacol 105: 696-702.

Nelson MT, Patlak JB, Worley JF, Standen NB 1990. Calcium channels, potassium channels, and voltage dependence of arterial smooth muscle tone. Am J Physiol 259: C3-C18.

Rahalison L, Hamburger M, Hostettman K, Monod M, Frenk E, Gupta MP, Santana AI, Correa MD, Gonzalez AG 1993. Screening for antifungal activity of Panamanian plants. Int J Pharmacog 31: 68-76.

Rees DD, Palmar RJM, Moncada S 1989. Role of endotheliumderived nitric oxide in the regulation of blood pressure. Proc Natl Acad Sci 86: 3375-3378.

Rusko J, Van Slooten G, Adams DJ 1995. Caffeine-evoked, calcium-sensitive membrane currents in rabbit aortic endothelial cells. Brit J Pharmacol 115: 133141. 